\title{
Editorial
}

\section{Routine use of \\ preoperative antacids for children undergoing elective surgery}

William M. Splinter MD FRCPC, G.V. Goresky BSc MDCM FRCPC
In the current issue of the Journal, Mikawa et al. ${ }^{1}$ present the results of their investigation evaluating the effects of a new proton inhibitor, lansoprazole, on the gastric fluid characteristics in children. This is a randomized, doubleblind, controlled study that was well executed. The investigators have identified appropriate conclusions based on the results of their study. However, this study along with many others conducted in recent years, does raise an important question related to the benefits of using prophylactic antacids. Can we now justify their routine use as a premedicant for children undergoing elective surgery?

Although the consequences of pulmonary aspiration of gastric contents are potentially life-threatening, perioperative pulmonary aspiration is a rare event amongst healthy children, despite the demonstration that they have a high volume of gastric fluid with low $\mathrm{pH}$. No patient, of the 40,240 anaesthetics studied in a prospective multicentre survey of anaesthesia-related paediatric morbidity and mortality, ${ }^{2}$ developed clinically important aspiration pneumonitis. This low incidence of aspiration pneumonitis is surprising because many studies have shown that a relatively large gastric fluid volume with low $\mathrm{pH}$ is present in the majority of children at the time of induction of anaesthesia.

Unfortunately, the cost of administering histamine receptor antagonists and proton pump inhibitors to prepare the gastric environment prior to elective surgery in healthy children is high, both in terms of convenience and financial burden. If we required all children undergoing elective surgery to be premedicated with lansoprazole, each patient would require a prescription, following assessment by a physician. Parents would require some education about the medication chosen, and they would be required to obtain the medication from a pharmacy.

From the Departments of Anaesthesia, Children's Hospital of Eastern Ontario, the University of Ottawa; and Alberta Children's Hospital at the University of Calgary.
On the basis of the recommendations by Mikawa $e t$ al., costs for lansoprazole, including dispensing fee, would be $\$ 12$ to $\$ 15$ for a $20 \mathrm{~kg}$ child. Administration of the premedication would inevitably result in some patients experiencing complications associated with its use (such as headaches, diarrhoea, constipation, fevers, eruptions, and, potentially, anaphylaxis), and complications associated with errors in drug administration (such as missed dosages and medication error).

We have known for several years that we can improve the gastric environment of children by the use of premedication, yet routine antacid prophylaxis prior to elective general anaesthesia has not become accepted practice. We believe that this is because the complication we wish to treat through the use of preoperative antacids is very rare. When we are dealing with rare events, such as lifethreatening aspiration pneumonia, the occurrence of an event such as an adverse drug reaction appears to be relatively common. Thus, routine antacid administration would be associated with an unacceptably high incidence of adverse drug reactions. Our assessment is that most anaesthetists find the cost:benefit ratio does not justify the routine use of preoperative antacids for children undergoing elective surgery.

Although we believe that lansoprazole and other antacids have no place for prophylactic use in otherwise healthy patients, we do not question its use for patients who are at increased risk of aspiration of gastric contents at the time of administration of general anaesthesia. Until we have evidence to the contrary, we will therefore continue to be advocates for the use of prophylactic antacids for patients with symptomatic gastroesophageal reflux, and for others (such as those who are known to have a potentially difficult airway) at known increased risk of pulmonary aspiration of gastric contents.

What, then, are the benefits of continued studies such as that by Mikawa et al., evaluating the use of premedicants to prepare the gastric environment before anaesthesia? Without such studies, we will not know the ef- 
ficacy, dose-response and safety of many drugs. Such studies are becoming especially important for those of us who practice paediatric anaesthesia, as many of the medications which we routinely use have been inadequately assessed in children.

For now, we still do not recommend the routine use of agents to prepare the gastric environment of children prior to elective general anaesthesia. We will, however, reevaluate our opinion, should a suitable investigation demonstrate an acceptable cost:benefit ratio for the routine use of such medications.

\section{L'utilisation de routine d'antiacides chez les enfants programmés pour une intervention non urgente}

Ce mois-ci, Mikawa et al. ${ }^{1}$ présentent leurs résultats de l'évaluation des effets d'un nouvel inhibiteur de protons, le lansoprasole, sur les propriétés du liquide gastrique de l'enfant. Il s'agit là d'une étude randomisée à double aveugle contrôlée et très bien exécutée: Les investigateurs en ont tiré des conclusions pertinentes. Cependant, cette étude, comme bien d'autres réalisées ces dernières années, soulève une question importante sur les bénéfices des antiacides prophylactiques. Peut-on justifier leur usage routinier chez des enfants soumis à une chirurgie non urgente?

Bien que les conséquences de l'aspiration par le.poumon du contenu gastrique soient potentiellement fatales, l'aspiration périopératoire survient rarement chez l'enfant en bonne santé, malgré le fait que le volume de son contenu gastrique soit important et que son $\mathrm{pH}$ soit abaissé. Lors d'une étude prospective sur la morbidité et la mortalité anesthésiques réalisée dans plusieurs centres pédiatriques portant sur 40240 anesthésie, aucun patient n'a développé de pneumonite d'aspiration cliniquement importante. Cette faible incidence de pneumonite d'aspiration surprend quand on sait que plusieurs études ont montré que, chez la majorité des enfants au moment de l'induction de l'anesthésie, le volume gastrique était très acide et relativement abondant.
Malheureusement, l'administration d'antagonistes des récepteurs de l'histamine et d'inhibiteurs de la pompe à protons avant une chirurgie non urgente chez des enfant bien portants est onéreuse aussi bien sous l'aspect pratique que sous l'aspect financier. Si nous exigons que tous les enfants programmés pour une chirurgie réglée soient prémédiqués au lansoprasole, une ordonnance serait requise pour chaque patient et devrait suivie dune visite par un médecin. Les parents auraient besoin de renseignements sur la médication choisie et ils devraient l'obtenir d'une pharmacie. Sur la base des recommandations de Mikawa et al., les coûts du lansoprasole, incluant les honoraires de pharmacien seraient de 12 à $15 \$$ pour un enfant de $20 \mathrm{~kg}$. L'administration de la prémédication provoquerait inévitablement des complication spécifiques au produit (céphalées, diarrhées, constipation, éruptions fièvre et peut-être de l'anaphylaxie) et des erreurs d'administration (comme des posologies fautives et des erreurs d'indentité).

Nous savons depuis plusieurs années que la composition du liquide gastrique chez l'enfant peut être modifiée par la prémédication, mais jusqu'à maintenant l'utilisation habituelle de la prophylaxie antiacide n'est jamais devenue pratique courante. Nous croyons que c'est parce que la complication que nous voulons de prévenir est rarissime. Quand nous considérons une complication aussi peu fréquente que la pneumonite d'aspiration, la survenue d'incidents tels que les réactions médicamenteuses semble relativement fréquente. Ainsi l'administration courante d'antiacides serait associée à une incidence élevée de réactions défavorables. Nous estimons que la plupart des anesthésistes sont d'avis que la balance coût-bénéfice ne justifie pas l'usage habituel d'antiacides en prémédication chez des enfants subissant une intervention chirurgicale réglée.

Nous ne croyons pas que le lansoprasole ou tout autre antiacide ait une rôle prophylactique à jouer chez les enfants en bonne santé, mais nous ne contestons pas leur nécessité chez dont le risque d'aspiration du contenu gastrique au moment de l'anesthésie générale est augmenté. Jusqu'à la preuve du contraire, nous allons continuer à promouvoir l'usage d'antiacides prophylactiques pour les porteurs de reflux gastro-oesophagien symptomatique et pour d'autres (comme ceux dont l'accès aux voies aériennes semble difficile) qui représentent un risque augmenté d'aspiration du contenu gastrique.

Pouvons-nous trouver des avantages à réaliser des études comme celle de Mikawa et al. qui évaluent des prémédications destinées à modifier les propriétés du liquide gastrique? Sans ces études, nous ne connaîtrions pas l'efficacité, la relation dose-effet et la marge de sécurité de plusieurs produits. De telles études sont particulièrement importantes pour les praticiens de l'anesthésie 
pédiatrique, car plusieurs des médications d'utilisation courante n'ont pas été éprouvées chez les enfants.

Nous ne recommandons pas maintenant l'usage courant d'agents qui modifient la composition du liquide gastrique chez les enfants avant une intervention programmée en chirurgie réglée. Cependant, nous sommes prêts à réviser cette position si jamais une investigation pertinente démontrait une balance coût-bénéfice favorable à l'usage de ce type de médication.

\section{References}

1 Mikawa K, Nishina K, Maekawa N, Asano M, Obara $H$. Lansoprazole reduces preoperative gastric fluid acidity and volume in children. Can J Anaesth 1995; 42: 467-72.

2 Tiret $L$, Nivoche $Y$, Hatton F, Desmonts JM, Vourch $G$. Complications related to anaesthesia in infants and children. Br J Anaesth 1988; 61: 263-9. 